\title{
The Hungarian Constitutional Court in Transition - from Actio Popularis to Constitutional Complaint
}

\begin{abstract}
In Hungary, the year 2012 brought a significant change in constitutional review. With modifying the competencies of the Constitutional Court, the Basic Law introduced three types of constitutional complaints and abolished actio popularis. Actio popularis was a well-functioning legal instrument in Hungarian law since the political transition of 1989-1990. Up until January 2012 anyone could request the abstract ex post facto constitutional review of a law or regulation. Unlike the former actio popularis, the essence of the new system of constitutional complaints is to have standing requirements for the complainants. Furthermore, new types of complaints are designed to defend constitutionality against personal injuries caused by ordinary courts as well. The article aims to describe actio popularis and constitutional complaints with regard to possible comparison of weaknesses and strong points. The author argues that regarding its effectiveness the new system do not yet provide a complete substitution for actio popularis.
\end{abstract}

Keywords: constitutional law, constitutional review, constitutional complaint, competencies of the Hungarian Constitutional Court

\section{Introduction}

The Hungarian Basic Law, ${ }^{1}$ effective from the first January 2012, has significantly modified the competencies of the Constitutional Court. Among several changes it introduced three types of constitutional complaints and abolished the former existing actio popularis. Actio popularis meant a legal possibility that anyone could turn to the Constitutional Court claiming that a law, legal provision or a regulation is contrary to a constitutional provision. The petitioner could also request the annulment of that piece of law. Constitutional complaint under former jurisdiction was to be lodged only in case of personal injury caused by the application of an unconstitutional norm. The aim of the new constitutional complaint mechanisms were to protect against personal injuries caused by ordinary courts and provide a possibility for constitutional review also in cases where the complainant cannot turn to ordinary court. Moreover, the Constitutional Court may supervise the constitutionality of legal provisions when applied in certain judicial cases and leads to unconstitutional court decision. This article first describes actio popularis and questions if actio popularis and constitutional complaint as such could be alternatives to each other. The second part gives a brief summary of the new constitutional complaint mechanisms in Hungary and about the practice of the Constitutional Court in the first semester of 2012. The author argues that concerning effective constitutional remedy the new system so far do not provide a complete

* Junior research fellow, Institute for Legal Studies, Centre for Social Sciences, Hungarian Academy of Sciences, H-1014 Budapest, Országház utca 30.

E-mail: fruzsina.orosz@gmail.com

${ }^{1}$ Called Fundamental Law in the wording of the official translation of the Hungarian constitution. For better understanding this paper uses the translation as Basic Law similarily to mainstream legal literature. 
substitution for actio popularis. Due to the fast transition several methodological questions of fundamental importance have to be answered during the first period of the operation of the new system.

\section{The actio popularis}

\section{Actio popularis in Hungary 1990-2011}

In Hungary, until the new constitution called Basic Law has turned into effect, approximately 1,600 actions were brought annually at the Constitutional Court within the framework of the abstract ex-post facto review of law (actio popularis) ${ }^{2}$ procedure, which has no standing requirement. The ordinary courts adjudicated violations of the rights of the individual, while the primary duty of the Constitutional Court was to review the constitutionality of laws and regulations. Even in the procedure of constitutional complaint, the Constitutional Court could only investigate the unconstitutionality of the challenged law or regulation, and this investigation did not have as a mandatory consequence the retroactive exclusion of the applicability of the unconstitutional law or regulation in the given case. ${ }^{3}$

Therefore, the duty of the Constitutional Court in Hungary, instead of protecting individual rights and the rights of the community and of the adjudication of specific cases, has been abstract constitutional review. ${ }^{4}$ The Constitution and the over 20 years of constitutional practice interpreting it demonstrated that the democratic protection of the rule of law is in the interest of all members of the society. This was the assumption behind the legal intrument adopted by Para. 32/A (4) of Act XX of 1949 (the Constitution), the socalled actio popularis.

Para. 21 of Act XXXII of 1989 (Act on the Constitutional Court), in force until January 1, 2012, determined who was entitled to initiate given procedures. Anyone could propose an action to initiate a proceeding for the ex-post facto review of a law or a public regulatory mechanism, or for the redress of an unconstitutional ommission. "Anyone" was defined by Constitutional Court practice to include actual natural and legal persons, who could even be foreign nationals or stateless people. The Court protected the assumption of the physical existence of the petitioner; generally, this was not something evidence was presented on.

The vast majority of the Constitutional Court's work consisted of the adjudication of these constitutional issues that could be proposed by anyone. ${ }^{5}$ With regard to the fact that at the political transition the Constitutional Court could not monitor the constitutionality of the entire legal system, as a consequence of action popularis, the cases that were heard came random. Alongside the fact that certain most important proceedings could be initiated by "anyone"-constitutionality in the democratic society was subject to the watchful scrutiny of the populus. The state effectively protected constitutionality with this broad opportunity

2 www.mkab.hu/letöltések/evkonyv.

3 About competencies of the Constitutional Court under the Act XXXII of 1989 on the Constitutional Court and about changes brought by the new Basic Law see in a nutshell The Constitutional Court. In: Csink, L.-Schanda, B.-Varga, Zs. A. (eds): The Basic Law of Hungary. Dublin, 2012. 157-167.

${ }^{4}$ Halmai, G.-Tóth, G. A. (eds): Emberi Jogok (Human Rights). Budapest, 2005. 215-216.

5 About the abolition of death penalty, see Decision 23/1990. (X. 31.) CC. About the official use of personal identification number see Decision 15/1991 (IV. 13.) CC. 
for bringing an action, declaring that the creation and preservation of constitutionality is in everyone's interest and right.

Over the course of the past 20 years, in spite of these internal values, actio popularis had become one of the most disputed elements in Hungarian Constitutional Court practice; one of the reasons for this was-as declared by even the president of the Constitutional Court-the unbearable workload, inhibiting the adjudication of the cases within a reasonable period of time. Consequently, the Basic Law introduced another form of protecting constitutionality; it eliminated the actio popularis, and enabled the bringing of an action on the basis of individual standing within the framework of a constitutional complaint, not only concerning unconstitutional decisions deriving from the application of an unconstitutional law or regulation, but also versus decisions or proceedings of an ordinary court or of an authority not providing the opportunity for a legal remedy.

With the elimination of the actio popularis, what has come to the foreground is the opportunity for anyone to go to the ombudsman and propose that in the case of an unconstitutional law or regulation, the Commissioner for Civil Rights commence a proceeding for an ex-post facto review of law before the Constitutional Court.

In order to ensure a fair transition between the actio popularis and the new system of constitutional complaints, during the first quarter of 2012, pursuant to the new Act on the Constitutional Court, ${ }^{6}$ those actio popularis motions could be submitted as constitutional complaints whose contents were originally targeted at the ex-post facto review of the constitutionality of a law or regulation and were not proposed by a person who would also have had standing to do so under the Basic Law. On the basis of the Act on the Constitutional Court, however, the petitioner of the terminated proceeding could only file the motion containing the constitutional concern in compliance with the law designated in the unadjudicated proposal, if his/her proposal also complied with the new rules applicable to constitutional law complaints (namely, Para. 26. (2) of the Basic Law) ${ }^{7}$ and the violation of constitutional rights referenced therein amounts to a violation of the Basic Law.

This means that even though as of the 1st of January, 2012, the ex-post facto review proceeding (actio popularis) that could be initiated by anyone had ceased to exist, the new Constitutional Court Act provided an opportunity for natural and legal persons to submit previously ex-post facto review of law motions as direct constitutional law complaints in such cases where the substantive content of their motion indicates a comprehensive compliance with the conditions applicable to the submission of a direct constitutional law complaint.

\section{The role of the actio popularis proceeding in constitutional adjudication}

The origin of actio popularis can be found as early as in Roman law. ${ }^{8}$ The word derives from the Latin words actio (action) and popularis (of the people). Many forms of actio popularis are known in constitutional law. When we mention actio popularis, this primarily means that anyone can initiate an ex-post facto review of law and can request the annulment of the law. There are states (e.g. Croatia), where in the case of such motion, the authority

6 Act CLI of 2011 on the Constitutional Court.

7 See intra. II. 1.2.

8 Mercier, P. P.: Citizens Right to Sue in the public interest: The Roman Actio popularis revisited, University of Western Ontario Law Review, 21 (1983), 89. and Nótári, T.: Római köz- és magánjog (Roman public law and private law). Kolozsvár, 2011. 277. 
conducting the constitutional review must take action, while there are some other states where the motion is only considered a proposal and it is the decision of the authority conducting the review as to whether to complete the proceeding (e.g. Israel). The type of constitutional complaint where the objective of the proceeding is the annulment of the law but the proposing party can only use this method of constitutional protection if the law is applied in his/her specific case, therefore he/she/it must show some kind of an involvement, is called quasy actio popularis (e.g. the Czech Republic). ${ }^{9}$

It was Kelsen, Austrian-American jurist and legal philosopher, who in 1928 first had used the expression actio popularis in his work in the context of constitutional law. According to Kelsen, actio popularis is the strongest guarantee to enable the filtering out of unconstitutional rules. Nonetheless, he did not recommend the introduction of such broad standing requirement into Austrian law, because in his view, the possibility for abuse was too large, as well as the fact that the Constitutional Court would have certainly become inundated with cases. ${ }^{10}$

Ex-post facto review of law proceedings that can be initiated by anyone are exceedingly rare in European constitutional law; to some extent, Bavaria (provides an opportunity to do so although the other German states and German federal states do not employ this form of initiating a proceeding), Croatia, Macedonia Republic of the Former Yugoslavia, Liechtenstein, Malta, Montenegro, Serbia and Slovenia. The system of constitutionality review and within it the circle of those who can initiate a proceeding is extremely varied in the various constitutional democracies. In some states, such as Lithuania only a group of Members of Parlament or the Government can initiate the review of the constitutionality of laws, in Estonia not even Members of Parlament can initiate such proceeding. ${ }^{11}$ There are states, however, which provide nearly unlimited access to the legal institution of constitutional review. ${ }^{12}$ An exemplary representative of this latter group was the system of actio popularis in Hungary, operating until the beginning of January 2012.

Thus, the essence of actio popularis is that it is not necessary that the petitioner has any interest in the success of the proceeding, meaning that it is not necessary for that person to be affected. For the most part, the countries establishing the opportunity for actio popularis come from the line of post-socialist nations. Actio popularis could be the most important tool of direct democracy in a transitional democracy. ${ }^{13}$ In the peaceful and effective management of transitioning into a constitutional democracy, constitutional observations by citizens affecting legislative activity may have a significant role, and this form of participation in exercising power may also greatly invigorate public sentiment and the sense of joint action. Thus, the introduction of actio popularis also reflects a kind of philosophy of democracy. The establishment of a proceeding which can be initiated by anyone in constitutional democracies is not a shared European minimum requirement in the area of reviewing the

9 Sadurski, W.: Rights before courts, a study of constitutional courts in postcommunist states of Central and Eastern Europe. The Netherlands, 2005. 6-7.

10 Arjomand, S. A.: Constitutional development and political reconstruction from nation building to new constitutionalism. In: Arjomand, S. A. (ed.): Constitutionalism and political reconstruction. The Netherlands, 2007. 39.

11 Sadurski: op. cit. 6-7.

12 More about the subject in Study No 538/2009 of the European Commission for democracy through law (Venice Commission): Study on individual access to constitutional justice.

13 Sólyom, L.: The role of constitutional courts in the transition to democracy-with special reference to Hungary. In: Arjomand (ed.): op. cit. 312. 
constitutionality of laws and regulations. For example, in the case of Montenegro, the Venice Commission of the Council of Europe did not recommend the introduction of actio popularis, citing Serbian experiences according to which the opportunity places undue burdens on the proceeding court. ${ }^{14}$ In the Commission's opinion 614/2011 dated March 28, 2011, however, it is stated that in Hungary the actio popularis was indeed able to filter out unconstitutional laws and regulations adopted prior to the effective date of the Constitution, during the years immediately following the political transition. ${ }^{15}$

\section{The actio popularis and the constitutional law complaint - alternatives?}

In legal literature, actio popularis is often presented as contrary to the proceeding initiated in the form of a constitutional complaint. ${ }^{16}$ The basis of the comparison is that while in the case of actio popularis it is part of its definition that there are no admissibility/standing criteria for the review of constitutionality, in the case of a constitutional complaint the authority conducting the review (generally the Constitutional Court or the Supreme Court) always expects that the initiating party be somehow involved in the case. In the case of the constitutional complaint, the primary objective of the complainant is to obtain legal remedy for their own case, as in the improvement of their own personal or financial position. The result of the proceeding can be the annulment of the unconstitutional law, just as in the case of the actio popularis based abstract designated review of the law; however, the annulment of the unconstitutional law from the perspective of the complainant is merely a tool to obtain legal redress in his/her/its own case. To the contrary, in actio popularis, the service of public interest, not the service of private interest, forms the backdrop. Although the two scopes of review can be contrasted from this perspective, the actio popularis and the constitutional law complaint are still not alternatives to each other; doctrinally, there is no obstacle to employing them side-by-side. In spite of this fact, in jurisprudence, the two legal institutions do not operate simultaneously in any nation. One partial reason for this is the workload limit of the authorities conducting the constitutionality review. A constitutional complaint with a broad scope and actio popularis cannot be employed in most countries without expensive structural expansions and operational reforms in such a way so the cases could be resolved within a reasonable length of time. The effective operation of legal remedy forums, meaning the realisation of the fundamental principle that the decisions be made within a proximity to the injured party, in an easily accessible and prompt manner, can suffer because of the complexity of the review system.

Contrary to actio popularis-the essence of which is that the Constitutional Court accepts a motion as long as the petitioner indicates which law or regulation is deemed unconstitutional and explains intelligently why-the substantive element of the constitutional law complaint is to set up the system of admissibility criteria, the essence of which is that a

14 Opinion on the Draft Law on the Constitutional Court of Montenegro of the European Commission for democracy through law (Venice Commission). Opinion 479/2008.

15 Opinion no. 614/2011. of the European Commission for democracy through law (Venice Commission) on three legal questions arising in the process of drafting the new cosntitution of Hungary.

16 E.g. Uitz, R.: May Less be More? Public Interest Standing and the Protection of Constitutional Rights. Lessons from Hungary's Actio Popularis. In: Pasquino, P.-Randazzo, B. (eds): La giustizia constituzionale ed i suoi utenti, Publicazioni dell'Institutio di Diritto Publico. no. 57, Milan, 2006. 89-117. 
law can be annuled only when its application in a specific case has led to a specific violation of a fundamental right. ${ }^{17}$ The admissibility criteria helps that actio popularis and constitutional complaints aiming for the annulment of a legal provision could be separated. Thus one can only request the abolition of an unconstitutional law in the framework of a constitutional law complaint, if the merit of the complainant's case in front of the ordinary court is significantly affected by the challenged law. Usually constitutional complaints can only be initiated in the case of the violation of the rights and freedoms of the complainant, while the actio popularis proceeding usually may be initiated in the case of the violation of any constitutional provision.

The constitutional complaint and the actio popularis may work with similar effectiveness regarding the filtering out of unconstitutional laws and regulations in the legal system. However, while the constitutional complaint, as a strong point, is able to redress individual violations of rights as well, it is a unique characteristic, a strong point of actio popularis that the petitioner there acts in the interest of maintaining constitutional democracy. Actio popularis as a legal institution relies on the participation of people taking action in the interest of the public.

\section{The new system of constitutional complaints in Hungary}

In the first few months of the Basic Law in effect, the Constitutional Court, alongside the drafting of a few substantive decisions mainly of lesser significance, established the procedural and substantive conditions of exercising its new competences. The Basic Law has changed the competences of the Constitutional Court, ${ }^{18}$ a new fundamental law governs the Constitutional Court ${ }^{19}$ (Abtv.). Under the new legislation, the composition of the cases changed completely. In May of 2012, of 686 pending cases, 536 were constitutional complaints, while in former years the constitutional complaints only comprised an insignificant portion of the Constitutional Court's caseload. In the first semester of 2012, approximately half of the constitutional complaints were based on Para. 26 (1) of the Abtv. (old type complaints), over a third were based on Para. 26 (2) of the Abtv. (direct complaint) and a smaller percentage was based on Para. 27 of the Abtv. (real complaint). ${ }^{20}$ The primary competence of the Constitutional Court has therefore shifted from the ex-post facto abstract review of laws to the adjudication of constitutional complaints.

Over the course of its preparation, during the first half of the year of its operation under the Basic Law, the Constitutional Court had prepared the intake of pending constitutional complaints supplemented on the basis of the Basic Law and also complaints initiated on the basis of a motion for an ex-post facto review of laws, submitted prior to January 1, 2012. Additionally, the general and specific tasks and their associated procedures in connection with the new constitutional complaints gained definition in the new organisational system. ${ }^{21}$ During the first semester of 2012, in addition to the continuous

17 Sadurski: op. cit. 7.

18 The Basic Law of Hungary (25 April 2011) Art. 24.

19 Act CLI of 2011 on the Constitutional Court.

20 www.mkab.hu/statisztika/2012.

21 Under the new legislation the Constitutional Court consists of 15 judges instead of the former 11 , and brings its decisions either in plenary session, in 5 member divisions or in a single judge procedure. See Decision I/2012 (I. 3) about the procedural rules of the Constitutional Court, I. chapter. 
discussion of procedural issues, the Court had clarified many dilemmas of a substantive nature as well. The discussion of procedural rules developed in connection with the adjudicability of constitutional complaints of various types on the merits (admissibility). It is well known that the procedure itself is also a substance: ${ }^{22}$ If constitutional law complaints are stuck as early as the intake procedure stage because of the strict conditions, few constitutional complaints remain to be decided on the merits. On the other hand, if the admissibility criteria are not self evident, abuses may take place during the intake stage of the case, or the inconsistent practice may violate the rule of law, a fundamental pillar of constitutional democracy.

\section{The three types of constitutional complaints}

Pursuant to Para. 24 (2) (c) of the Basic Law, on the basis of a constitutional complaint, the Constitutional Court reviews the compliance of the law or regulation applied in the given case with the Basic Law (old type and direct constitutional law complaint). Pursuant to Para. 24 (2) (d) of the Basic Law, on the basis of the constitutional complaint, the Constitutional Court also reviews the compliance of the court decision with the Basic Law (new type, real complaint). By breaking down the rules contained in the Basic Law, the Act on the Constitutional Court established three categories of constitutional complaints.

\subsection{The old type complaint}

Pursuant to Para. 26 (1) of the Abtv. according to Para. 24 (2) (c) of the Basic Law, a person or organisation affected in an individual case may turn to the Constitutional Court with a constitutional complaint, as long as over the course of the application of an unconstitutional law in the court proceeding conducted in the matter, a violation of his/her/its rights has occurred and he/she/it had already exhausted available legal remedies or legal redress is unavailable. This is what we call the old type constitutional law complaint.

Constitutional complaints submitted pursuant to Act XXXII of 1989 remained pending also as old type constitutional complaints, as long as pursuant to the decree of the Constitutional Court, the complainant supplemented his/her/its complaint within the alloted deadline (31 March 2012) with the provisions of the Basic Law violated by the challenged legal instrument and associated information regarding related constitutional correlations, as well as the certification of legal representation required by the new Abtv.

Pursuant to Para. 73 (1) of the Abtv., in pending cases before the Constitutional Court, the proceeding of the Constitutional Court must be conducted in accordance with the provisions of the Abtv., if the case can be examined in conjunction with the mandates of the Basic Law and the standing of the petitioner is established pursuant to the provisions of the new Abtv. In case of constitutional law complaints originally submitted prior to December 31, 2011 and still pending on January 1, 2012, in its decree ordering the supplementation of the motion, the Constitutional Court also set a deadline of March 31, 2012.

\subsection{The direct constitutional complaint}

Pursuant to Para. 26 (2) of the Abtv., unlike in Section (1), as an exception, the proceeding of the Constitutional Court can commence when by virtue of the application or effect of the unconstitutional provision the violation of the filing party's rights had occurred directly,

22 Tóth, G. A.: Az eljárási alkotmányosság tartalma (The meaning of procedural constitutionality). Fundamentum, (2004) 3, 5-33. 
without a court decision, and no legal remedy is available to redress the unconstitutional situation, or the petitioners had already exhausted their legal remedies. This is what is called a direct constitutional complaint.

Newly submitted motions that are based on actio popularis motions from before 2012 are also treated as direct constitutional complaints. In the case of such constitutional complaints, it was also a condition (although the petitioners did not generally take this into account) that if the legal regulatory framework enabled the petitioner to turn to an authority or a court, they had to exhaust such opportunities for legal remedy.

From a constitutional law perspective, many have considered it worrysome that pending proceedings on December 31, 2011 cannot be completed pursuant to previously valid law. More moderate opinions merely thought it desirable that those motions which request the completion of a proceeding regarding a violation of the Constitution which at the same time can be interpreted as a violation of the Basic Law should be allowed to be resubmitted in some form to the Constitutional Court. ${ }^{23}$

As a result of the transitional provisions, many motions previously submitted as actio popularis became filtered as constitutional complaints through the admissibility procedure. The legislator provided a solution in order to keep the petitioners who have been waiting, in some cases, for many years, from feeling deprived of their constitutional rights. En masse, however, transforming motions indicating unconstitutionality in abstracto into acceptable constitutional complaints will certainly not be successful, because the original complaints were not designed to show injury to an individual's rights.

\subsection{The real constitutional complaint}

Pursuant to Para. 27 of the Abtv., according to Para. 24 (2) (d) of the Basic Law, the affected person or organisation in a given case can turn to the Constitutional Court against a court decision that is contrary to the Basic Law, if the substantive case decision or other decision concluding the court proceeding violates the rights of the complainants in the Basic Law and the petitioners had already exhausted their legal remedies or no legal remedies had been made available. This is what is called a real constitutional complaint.

The real constitutional complaint is known from German law and has been a desired legal institution in Hungary by many for a long time. ${ }^{24}$ Its practice-meaning the activity of the Federal Constitutional Court of Germany of reviewing the decisions of the ordinary courts from a constitutionality perspective-eases the development of uniform standards of constitutionality to be applied by the courts. After the binding conclusion of the lawsuit violating the party's fundamental rights, the party can turn to the Constitutional Court pursuant to Para. 93 (1) (4) (a) of the Basic Law. The legal literature of past decades distinguished the German and Hungarian type of constitutional complaints with the adjective "real". In the case of the Hungarian type, pursuant to Act XXXII of 1989 on the Constitutional Court, the affected party could only turn to the Constitutional Court with a motion requesting the annulment of the law applied in her case. Above annulment, it could only be stated in individual, specially justified cases that the application of the unconstitutional provision in the case of the complainant is retroactively excluded by the Constitutional Court. Consequently, in the past the party submitting the constitutional

$23 \mathrm{http} / / /$ tasz.hu/files/tasz/imce/2011/Abtv.elemzes_20111027_final.pdf.

${ }^{24}$ E.g. Halmai, G.: Az Alkotmány mint norma a bírói jogalkalmazásban (The Constitution as a norm in judicial adjudication). Fundamentum, (1998) 3, 77-81. 
complaint could not request the potential review of the constitutionality of the litigation proceeding and of the ordinary court decision.

The institution of the real constitutional complaint is of crucial importance because it creates an opportunity for the Constitutional Court to monitor the activity of ordinaty courts besides monitoring the activity of the legislator. The review is conducted from a constitutional perspective, the Constitutional Court has to adjudicate whether the interpretation of civil law, of the law of public administration or of criminal law complied with the Basic Law. This so-called real constitutional law complaint, however, also has its limits in German law: Constitutional review is possible only if the Court's decision is based on a material misinterpretation of the basic Law, with particular focus on the extent of the violation thereof. ${ }^{25}$ In the interest of preserving the allocation of functions, separation of powers between the courts and the Constitutional Court, the Federal Constitutional Court of Germany established, as early as in the first volume of published decisions, the designation of special constitutional issue (Specifisches Verfassungsrecht). ${ }^{26}$ The Federal Constitutional Court of Germany stated that conducting the proceeding, the finding and evaluation of the facts, the interpretation of the laws and their application to the given case continue to be the duty of ordinary courts and are exempted from the review of the Federal Constitutional Court, except when it concerns a "special constitutional issue". ${ }^{27}$

The so-called special constitutional issue gained its currently valid form in 1964, in the decision issued in a patent law case, the "Heck'sche formula". ${ }^{28}$ In essence, this means that the Federal Constitutional Court of Germany does not review the constitutionality of the decision in all cases, only when it concerns a special constitutionality issue. As expressed in Bürgschaft and similar, as early as in the Mephisto case, the Federal Constitutional Court of Germany stated that without the suspicion of a special constitutional issue, the Federal Constitutional Court is not entitled to review a decision even if presumably it would come to a different conclusion on the merits than the court adjudicating the civil case. ${ }^{29}$

Laws and regulations somehow always impact fundamental rights. It would be contrary to the principle of separation of powers and consequently with the goals of the Constitutional Court if in all cases one could turn to the Constitutional Court as the final judicial forum. The interpretation of laws and regulations and their application in a given case is the duty of the ordinary courts. Thus, in the framework of a constitutional complaint, one can only turn to the Constitutional Court if the petitioner can substantiate the probability that the constitutional problem arising over the course of the judicial proceeding is of particular constitutional significance.

In German legal practice, the Federal Constitutional Court of Germany first examines whether the motion contains a special constitutional issue. Therefore, the error of the disputed court decision must be based on the court ignoring the fundamental rights or

25 BVerfG 7 February 1990, BVerGE 81, 242 (Handelsvertreter), 253; BVerfg 19 October 1993, BVerfgE 89, 214 (Bürgschaft) 230.

${ }^{26}$ Kenntner cited by Zakariás, K.: A rendes bíróságok határozatainak alkotmányossági felülvizsgálata a német Szövetségi Alkotmánybíróság gyakorlatában (Constitutional supervision of decisions of ordinary courts in the practice of German Constitutional Court). Jogtudományi Közlöny, (2010) 2, 98, 102.

271 BVerGE, 418 (420), cited by Zakariás: op. cit. 102.

28 It is named after Karl Heck, judge of the constitutional court. See Zakariás: op. cit. 98, 102.

29 BVerfg 19 October 1993, BVerfgE 89, 214 (Bürgschaft) 230. 
incorrectly applying the law to a significant constitutional degree ${ }^{30}$ First, it is those errors in interpretation that can become special constitutional issues which mean the fundamental modification of the meaning of a fundamental right and in the context of a specific case, are also significant in a substantive legal sense.

\section{Admissibility in the practice of the Constitutional Court}

Over the course of adjudicating constitutional complaints, the Constitutional Court faced many interpretive tasks. The clarification of issues in connection with the admissibility of a motion and the development of procedure and doctrine will fundamentally define how constitutional law complaint legal remedies will operate in Hungary.

\subsection{Involvement ${ }^{31}$}

Pursuant to Para. 26 and Para. 27 of the Abtv., a condition of submitting constitutional complaints is the verification of personal involvement. Pursuant to Para. 52 (4) of the Abtv., compliance with the conditions of the Constitutional Court proceeding must be verified by the petitioner, therefore it is not enough to refer to involvement in the motion, but all the verifying, as in evidentiary facts that prove that fact; when necessary, associated documents must be attached. ${ }^{32}$ It is the subject of this stage of the admissions procedure whether the petitioner can verify that the application or entering into force of the law or regulation had subjected her to personal or direct violation of her right(s). ${ }^{33}$

Even though in its decisions rejecting the admissibility of constitutional complaints, the Constitutional Court does not disclose all reasons underlying the decision, in related notes it does reference the details and results of the review. In constitutional complaint proceedings lodged on the basis of Para. 26 (1) and Para. 27 of the Abtv., the petitioner challenges a court decision. In this case, the review of involvement is generally problemfree, as typically involved parties are those whose rights or lawful interests is directly affected by the challenged court decision. In the case of direct complaints lodged pursuant to Para. 26 (2) of the Abtv., however, the showing of involvement is a considerably more difficult task. In this area, one cannot talk of solidified standards and consistently applied rules, trends can be observed instead. The Constitutional Court visibly strives to delienate the direct constitutional law complaint from the actio popularis proceeding. ${ }^{34}$

The problem is sharply outlined in the case of constitutional complaints former submitted as an actio popularis motion prior to the effective date of the Basic Law. In many cases, the petitioners have submitted their earlier motion requesting an abstract ex-post facto review of law without going into detail on the issue of direct involvement and suffered violation of fundamental rights. Cases were rejected, for example, where in connection with the reform of the pension fund system reform, the petitioners verified their involvement with their private pension fund memberships. ${ }^{35}$ The essence of the justification of the

3018 BVerGE, 85. (92).

31 This subchapter is based on the following article: Bitskey, B.-Gárdos-Orosz, F.: A befogadható alkotmányjogi panasz: az első hónapok tapasztalatai (The admissible constitutional complaint: first experiences). Alkotmánybírósági Szemle, (2012) 2, 93-95.

32 Decision 3105/2012. (VI. 26.) CC.

33 Decision 3063/2012. (VII. 26.) CC.

34 E.g. Decision 3105/2012. (VI. 26.) CC.

35 Decision IV/2856/2012. CC. 
decision-similarly to other pension fund $\operatorname{cases}^{36}$-is that involvement cannot be determined because the referenced provisions only affect the complainant in the event of their future application.

In an other case, complainants, in constitutional complaints directed at the finding of government activity counter to the Basic Law in an effort to exclusively possess power, have based their personal involvement on the fact that in the text of Article C, Paragraph $(2)^{37}$ Basic Law the word "everybody" is expressly set forth, a concept which encompasses all Hungarian natural persons and organisations, including the petitioner itself. On the basis of all of the above-according to the petitioners-anyone can submit a constitutional complaint if the challenged laws and regulations serve the forceful acquisition or exercise of power, or its exclusive possession.

According to the position of the Constitutional Court, the referenced law sections have not been applied against the petitioners, either directly or indirectly, and their coming into force did not affect them directly, their individual rights were not impinged upon by the adoption of the challenged provisions. For all of the foregoing, the Constitutional Court had rejected the admission of the complaint. ${ }^{38}$

The reasoning shows that personal involvement as an admissibility criterion sharply separates actio popularis and the new type of constitutional complaint. Thus, it is not enough to form the foundation of the motion that the petitioner is subject to the effects of the law; an actual, verified, personal injury at law must be indicated to have direct involvement.

Upon the examination of personal, direct involvement, it is, however, not desirable to draw a distinction between petitioners as to whether they suffered an injury to their rights because of the entering into force of a law which has an effect on large numbers of people or because of one which expresses general rules applicable to smaller groups.

The doctrinal development of direct and personal involvement requires great effort. In the case of a direct complaint contained in Para. 26 (2) of the Abtv., it has been found that on the basis of those laws, and other legal mechanisms defined in Para. 37 (2) of the Abtv., which cannot enter into force directly by their nature (such as a resolution for the uniformity of law, which is only binding on the courts, or generally those laws and regulations which govern the proceedings of authorities and courts, etc.), direct involvement cannot be determined. The legal injury in such cases can necessarily only take place through a court or authority proceeding and action, therefore only an old type constitutional complaint can be initiated pursuant to Para. 26 (1). ${ }^{39}$

The directness of the involvement could be also defined by the weight of suffered disadvantages. The evaluation of the issue is doctrinally complex, however, because it is connected with the criteria applicable to the raising of the fundamental constitutionality issue contained in Para. 29 of the Abtv. It is an interesting problem how the weight of the injury to rights and the directness of involvement are interconnected.

36 Decision 3020/2012. (VI. 21.) CC.

37 "No activity of anyone may be directed at the acquisition or exercise of public authority by force, nor at its exclusive possession...".

38 Referring to Art. 64 b) of the Act CLI of 2011 on the Constitutional Court and Art. 30 (2) of the Procedural Rules of the Constitutional Court.

39 E.g. Decision 3114/2012. (VII. 26.) CC. 
In connection with involvement, it is also a question as to whether a constitutional complaint can only be submitted in case of an injury at fundamental rights, or in case of any other right provided for in the Basic Law; possibly in case of the violation of constitutional values or in case of unconstitutional omission of the legislator. This latter problem is highlighted by those complaints that are based on the violation of the concept of rule of law. ${ }^{40}$

With regard to the issue of involvement, two more interesting problems are definitely worth mentioning from the first half year of practice of the Constitutional Court, in 2012. The first is that in the case of certain sector specific, code type laws (for example, laws and regulations concerning public education) it has been an ordinary occurrence that advocacy groups and trade unions submitted constitutional complaints with regard to such laws or regulations which did not affect their rights personally, only the rights of certain employees or the rights of practicioners of a given profession. In this case, however, the Constitutional Court held that only individual, specifically involved persons can submit the complaint, the union for example is not entitled to do so, as it is not directly involved. ${ }^{41}$

\subsection{A fundamental issue of constitutional significance}

With regard to constitutional complaints, in addition to the Abtv., the Procedural Code of the Constitutional Court set forth additional rules. Pursuant to Para. 29 of the Abtv., the Constitutional Court shall only admit constitutional complaints in the event of a conflict with the Basic Law which materially influences the court decision or in the case of an issue of constitutional significance. Paragraph 30 (2) of the Procedural Code, however, lists this admissions criterion as the Constitutional Court shall deny the admission of the constitutional complaint if the petitioner does not claim conflict with the Basic Law which materially influences the disputed court decision, or the problem raised is not a fundamental issue of constitutional law.

Even though the two forms of the statement could mean the same thing grammatically, the practice of the Constitutional Court to date shows that it could be a matter of dispute as to how the two "or" criteria can be interpreted. Contrary to the Abtv., one of the ways the Procedural Code is interpreted is when the "or" criterion in the law becomes a conjunctive condition. If the text of the Procedural Code provides an opportunity to deny the admission of the complaint, if it does not raise a significant constitutional issue or this question did not influence on the merits the court's decision, it actually requires that both criteria are met at the same time for admission.

As a consequence of the foregoing, even though for admission, pursuant to the text of the Abtv., it is sufficient in and of itself if the problem raised has fundamental constitutional significance, having made that finding, the Constitutional Court will also review whether the constitutional law issue had materially influenced the court decision. By the same token, even if the Constitutional Court had determined that the constitutional law question had materially influenced the court decision, it could be an additional question as to whether that was of a fundamental constitutional significance.

It can assist in understanding the problem if at the time of examining the admission issues, we account for the possible legal consequence related dilemmas as well. The true question behind the admissions disputes is perhaps that it cannot yet be seen what the legal

40 See supra Polish regulation.

41 Decision 3091/2012. (VII. 26.) CC. 
consequence is in the case of a constitutional complaint which successfully designates the fundamental constitutionality problem, but cannot show that it had materially influenced the court decision. ${ }^{42}$

This dilemma is most understandable in the case of real constitutional complaints pursuant to Para. 27 of the Abtv., as here it must be weighed how the legal consequence resulting from the vacating of the court decision is warranted when the decision was not actually materially influenced by the significant constitutional issue. Even in the case of complaints lodged on the basis of Para. 26 (1), this question remains in effect, but in the case of old type complaints, the legal consequence that is doctrinally easier to trace from the regulatory framework is the annulment of the law independently, while keeping the challenged court decision in force.

In the old procedural system pursuant to Act XXXII of 1989 on the Constitutional Court, in the case of constitutional law complaints, in addition to the annulment of the law or regulation, the Constitutional Court could make a decision regarding the exclusion of the applicability of the unconstitutional law or regulation. The Constitutional Court could decide in a similar manner regarding the fate of the law and of the court decision.

In the framework of a direct constitutional complaint, the Constitutional Court had received such motion where the petitioner found the text "special exception" in Para. 26 (2) of the Abtv. and the "or an issue of fundamental constitutional significance" test in Para. 29 of the Abtv. unconstitutional. In the petitioner's view, these provisions conflict with Para. 24 (2) (c) of the Basic Law because they might deprive one of the opportunity to submit a constitutional complaint to be provided in any case against laws and regulations that are contrary to the Basic Law. The fact that Para. 26 (2) only enables the injured party to attack a law or provision that are contrary to the Basic Law as an exception is a material limitation on the right to turn to the Constitutional Court and makes the initiation of the proceeding unpredictable. ${ }^{43}$

In the first half a year of practice by the Constitutional Court, few guidelines can be gleaned to assist in the definition of Para. 29 of the Abtv. It can be seen, however, that in nearly all cases the Constitutional Court had rejected the admission of the motions because of the absence of an issue of fundamental constitutional significance. There were multiple cases in which the reason why the Constitutional Court did not see an issue of fundamental constitutional significance was because the constitutional complaint raised such issues in which the Constitutional Court had decided in the past. ${ }^{44}$ It is important to highlight that in these cases the decisions did not employ the doctrine of res judicata, the reasoning did not refer to the fact that the Constitutional Court had already made a decision with regard to the given law or regulation, but rather it emphasised that a constitutional issue on which the Constitutional Court had already issued a decision on cannot be of fundamental significance. $^{45}$

${ }^{42}$ Refusal of the complaint (Inadmissibility) was justified with not forseeable or not satisfactory possible remedies, e.g. Decision 3003/2012. (VI. 21.) CC.

43 Decision IV/02229/2012. CC.

44 E.g. Decision 3004/2012. (VI. 21.). CC.

45 Worries about res judicata [e.g. Decision 3005/2012. (VI. 21.) CC. or Decision 3083/2012. (VII. 26.) CC.] see http://tasz.hu/files/tasz/imce/2011/Abtv._elemzes_20111027_final.pdf. 


\section{Conclusion}

In January 2012, a broad array of constitutional complaints had been introduced to Hungarian constitutional law. During the transitional period of constitutional review from actio popularis to a complex system of constitutional complaints, the majority of complaint proceedings resulted in the denial of the admissibility of the motion. The petitioners were experiencing the same problems in Hungarian law as the ones acting under the previously valid law. For the most part, this means cases in connection with the use of wheel clamps, rules on keeping animals or landscaping, local taxes (e.g. special taxes, fees), or pension regulation. Even these frequently received petitions rarely comply with the procedural and most of all, content requirements applicable to new constitutional complaints.

The development of constitutional democracy following the political transition in 1989 was effectively assisted by the legal institution of actio popularis. Hungary could be an example to the entire world for how constitutional protection operates smoothly as a result of the mostly public-interest driven action of natural and legal persons. There might have been good reasons in Hungarian law for introducing the new types of constitutional complaint. The new system enables the monitoring of the constitutionality of court decisions simultaneously with the constitutional review of laws and regulations. The expectations, however, are rather high, as the new type of constitutional protection did not complete but replaced a fundamentally well functioning system. 